10 Rösen P, Schrör K. Increased prostacyclin release from perfused hearts of acutely diabetic rats. Diabetologia 1980;18:391-4.

11 Davis TME, Mitchell MD, Turner RC. Prostacyclin and thromboxane metabolites in diabetes. Lancet 1979;ii :789-90.

12 Davis TME, Mitchell MD, Dornan TL, et al. Plasma 6-keto-PGF ${ }_{1}$ concentrations and diabetic retinopathy. Lancet $1980 ; \mathrm{i}: 373$.

${ }^{13}$ Dollery CT, Friedman LA, Hensby CN, et al. Circulating prostacyclin may be reduced in diabetes. Lancet 1979 ;ii:1365.

14 Mitchell MD. A sensitive radioimmunoassay for 6-keto-PGF $1 \alpha$ : preliminary observations on circulating concentrations. Prostaglandins Med 1978; 1:13-21.

15 Kynoch PAM, Lehman H. Rapid estimation ( $2 \frac{1}{2} \mathrm{~h}$ ) of glycosylated haemoglobins for routine purposes. Lancet 1977 ;ii:16.

${ }_{16}$ De Bono D. En Face organ culture of vascular endothelium. Br $\mathcal{F}$ Exp Pathol 1975;56:8-13.
17 Reinsch CH. Smoothing by spline functions. Numerische Mathematik 1967; س్ 10:177-83.

18 Siegel S. Non-parametric statistics. New York: McGraw Hill, 1956.

19 Moncada S, Higgs EA, Vane JR. Human arterial and venous tissues generate prostacyclin (prostaglandin $\mathrm{X}$ ), a potent inhibitor of platelet $C$ aggregation. Lancet $1977 ; \mathrm{i}: 18-20$

${ }^{20}$ Jorgensen KA, Stoffersen E, Dyerberg J. Stability of prostacyclin in plasma. Lancet $1979 ; \mathrm{i}: 1352$.

${ }^{21}$ Pace-Asciak CR, Carrara MC. Age-dependent increase in the formation of prostaglandin $I_{2}$ by intact and homogenised aortae from the developing $\infty$ spontaneously hypertensive rat. Biochim Biophys Acta 1979;574:177-81. T)

22 Steer ML, MacIntyre DE, Levine L, et al. Is prostacyclin a physiologically important circulating anti-platelet agent? Nature 1980 ;283:194-5.

(Accepted 3 February 1981)

\title{
Impaired monocyte function in liver cirrhosis
}

\author{
AVI HASSNER, YEHUDIT KLETTER, DORIT SHLAG, MEDINA YEDVAB, MOSHE ARONSON, \\ SHLOMO SHIBOLET
}

\begin{abstract}
Monocyte function in patients with cirrhosis of the liver was measured by phagocytosis and killing of Candida pseudotropicalis and $C$ albicans. Both variables were significantly decreased in the patients compared with controls. Control monocytes exposed for two hours to patients' serum showed a significant decrease in intracellular killing compared with control monocytes incubated in autologous serum. This suggests the presence of an inhibiting factor in the patients' serum. This inhibitory factor passed through a dialysis membrane that permitted the passage of molecules of less than 12000 daltons. Treating monocytes from patients with trypsin significantly increased phagocytosis, indicating that the possible inhibitory factor was attached to the monocyte surface. Metabolism of monocytes during phagocytosis as determined by chemoluminescence was significantly lower in monocytes from patients compared with controls, indicating metabolic impairment.

Monocytes are a component of the monocyte-macrophage system, which includes Kupffer's cells. Impairment of the function of these cells, which have a pivotal role in clearing portal blood, might well be extremely important in the development of chronic liver disease.
\end{abstract}

Department of Medicine D, Ichilov Municipal Hospital of Tel-Aviv, and Department of Histology and Cell Biology, Sackler School of Medicine, Tel-Aviv University, Tel-Aviv, Israel

AVI HASSNER, MD, house physician and instructor in internal medicine YEHUDIT KLETTER, PHD, research fellow, department of histology and cell biology

DORIT SHLAG, MD, house physician

MEDINA YEDVAB, MD, deputy head of department of internal medicine and lecturer

MOSHE ARONSON, PHD, associate professor, department of histology and cell biology

SHLOMO SHIBOLET, MD, head of department of internal medicine and associate professor

\section{Introduction}

Various defects have been described in the immune defence system of patients with liver cirrhosis that might explain the increased susceptibility of these patients to infection. Impaired delayed hypersensitivity reactions, ${ }^{1}$ impaired humoral function, ${ }^{2}$ and impaired production of complement by the diseased liver ${ }^{2} \vec{E}$ have been described. In a review on this subject, however, Sherlock ${ }^{3}$ stated that there were no data showing decreased function of Kupffer's cells in liver cirrhosis but as a result of collateral circulation these cells were bypassed. While Kupffer's cells and monocytes are considered to be components of the monocyte-macrophage system, ${ }^{4}$ evaluation of monocyte function in patients with cirrhosis of the liver might contribute to our understanding of the factors leading to the increased tendency for infection. We therefore investigated phagocytosis and intracellular killing by blood monocytes from patients with liver cirrhosis.

\section{Subjects and methods}

We studied 40 patients ( 17 women, 23 men) who had liver cirrhosis that had been proved on biopsy. The mean age was 41 (range 25-67) years. Twenty-eight patients had alcoholic cirrhosis, eight postnecrotic cirrhosis, and the others cryptogenic or an undefined type of liver cirrhosis. None had signs of infection during the study, and none received antibiotics, steroids, or other immunosuppressive drugs. We also studied 32 subjects ( 12 women, 20 men) who were healthy or had angina and served as control group. None of them had diabetes mellitus or received drugs during the study.

Mononuclear cells from heparinised venous blood were isolated by buoyant centrifugation in Ficoll-Paque (Pharmacia). ${ }^{5}$ Candida pseudotropicalis and $C$ albicans were grown and phagocytosis and intracellular killing measured according to the method of Territo and Cline. ${ }^{6}$ Serum from patients was dialysed for 24 hours at $4^{\circ} \mathrm{C}$ against physiological saline through dialysis tubing with a 12000 dalton cut-off (A $\mathrm{H}$ Thomas Co, Philadelphia, USA). Monocytes from healthy donors were incubated for 120 minutes at $4^{\circ} \mathrm{C}$ in autologous serum, untreated patients' serum, and patients' serum after dialysis. After incubation the cells were washed twice in Hanks's Balanced Salt Solution and heparin, and phagocytosis and intracellular killing in autologous serum were measured. Monocytes from patients were incubated for 30 minutes at $37^{\circ} \mathrm{C}$ in $0.25 \%$ trypsin, washed twice, and their function subsequently evaluated.

Chemoluminescence was measured in monocytes from the controls and patients 30 minutes after incubation with $C$ albicans in autologous 
serum. Measurements were performed in a scintillation counter (Packared Tri-Carb 3255) for 30 seconds. $^{?}$

Statistical significance was evaluated using Student's $t$ test.

\section{Results}

The tables summarise phagocytosis and intracellular killing of candida by the monocytes. Table I shows that there was a distinct decrease in phagocytosis and intracellular killing of both Candida species by monocytes from patients as compared with monocytes from controls.

TABLE I-Phagocytosis (mean $\pm S D$ number of yeast cells/monocyte) and intracellular killing (mean $+S D$ percentage of killed yeast cells) by monocytes from control subjects and patients with liver cirrhosis

\begin{tabular}{|c|c|c|c|}
\hline & $\begin{array}{l}\text { Patients } \\
\text { (group 1) }\end{array}$ & $\begin{array}{l}\text { Controls } \\
\text { (group 2) }\end{array}$ & $\begin{array}{l}\text { Patients } \\
\text { (monocytes } \\
\text { exposed to } \\
\text { trypsin) } \\
\text { (group 3) }\end{array}$ \\
\hline \multicolumn{4}{|c|}{ Phagocytosis } \\
\hline $\begin{array}{l}C \text { pseudotropicalis } \\
\text { Groups } 1 v 2 \text { and } 1 v 3 \\
C \text { albicans } \\
\text { Groups } 1 v 2 \text { and } 1 v 3\end{array}$ & $\begin{array}{l}1 \cdot 19 \pm 0.07 \\
1.23 \pm 0.07\end{array}$ & $\begin{array}{l}1 \cdot 27 \pm 0.08 \\
p<0.0025 \\
1.33 \pm 0.11 \\
p<0.0025\end{array}$ & $\begin{array}{l}1 \cdot 45 \pm 0 \cdot 15 \\
\mathrm{p}<0.0005 \\
1.54 \pm 0 \cdot 11 \\
\mathrm{p}<0.0005\end{array}$ \\
\hline \multicolumn{4}{|c|}{ Intracellular killing } \\
\hline $\begin{array}{l}C \text { pseudotropicalis } \\
\text { Groups } 1 \text { v } 2 \text { and } 1 v 3 \\
C \text { albicans } \\
\text { Groups } 1 \text { v } 2 \text { and } 1 v 3\end{array}$ & $\begin{array}{l}25 \cdot 07 \pm 6 \cdot 03 \\
27 \cdot 81+9 \cdot 25\end{array}$ & $\begin{array}{l}39 \cdot 95+8 \cdot 32 \\
p<0.0005 \\
42 \cdot 98+7.07 \\
p<0.0005\end{array}$ & $\begin{array}{l}21 \cdot 2+3 \cdot 75 \\
p<0 \cdot 01 \\
24 \cdot 76+4 \cdot 9 \\
p<0.05\end{array}$ \\
\hline
\end{tabular}

Table II shows phagocytosis and intracellular killing by normal monocytes after incubation in patients' serum, dialysed patients' serum, and normal serum. Intracellular killing but not phagocytosis was reduced when the normal monocytes were incubated in patients' serum. When patients' serum was dialysed through a membrane permitting passage of molecules of less than 12000 daltons it lost its inhibiting capacity and no difference in intracellular killing was found. After exposure of monocytes to trypsin phagocytosis was increased, possibly indicating that an inhibitory factor has been removed from the surface of these monocytes (table I). Chemoluminescence (expressed as mean $\pm \mathrm{SD} \mathrm{cpm} \times 10^{5} / 10^{5}$ monocytes in 30 seconds) was $2.64 \pm 1.62$ in the patients' monocytes and $7.62 \pm 6.16$ in the control monocytes. This difference is significant $(p<0.025)$. These data indicate an impairment of metabolism in the patients' monocytes, which might also be linked to the inhibitory factor in their serum.

TABLE II-Effect of serum on phagocytosis (mean $\pm S D$ number of yeast cells/ monocyte) and intracellular killing (mean $\pm S D$ percentage of killed yeast cells) by normal monocytes

\begin{tabular}{|c|c|c|c|}
\hline & \multicolumn{3}{|c|}{ Control monocytes exposed for two hours to: } \\
\hline & $\begin{array}{l}\text { Patients' } \\
\text { serum } \\
\text { (group i) }\end{array}$ & $\begin{array}{l}\text { Autologous } \\
\text { serum } \\
\text { (group 2) }\end{array}$ & $\begin{array}{l}\text { Patients' serum } \\
\text { after dialysis } \\
\text { (group 3) }\end{array}$ \\
\hline \multicolumn{4}{|c|}{ Phagocytosis } \\
\hline$C$ pseudotropicalis & $1 \cdot 32+0.04$ & $1.32+0.04$ & $1.35+0.05$ \\
\hline $\begin{array}{l}C \text { albicans } 1 v 2 \text { and } 1 v 3 \\
\text { Groups } 1 v 2 \text { and } 1 v 3\end{array}$ & $1.39+0.04$ & $\begin{array}{c}1 \cdot 39 \pm 0.07 \\
\text { NS }\end{array}$ & $\begin{array}{l}\text { NS } \\
1.45 \pm 0.07 \\
p<0.025\end{array}$ \\
\hline \multicolumn{4}{|c|}{ Intracellular killing } \\
\hline$C$ pseudotropicalis & $30 \cdot 78+2 \cdot 1$ & $42 \cdot 37+4 \cdot 16$ & $40 \cdot 57 \div 6 \cdot 36$ \\
\hline $\begin{array}{l}C \text { albicans } \\
\text { Groups } 1 v 2 \text { and } 1 v 3\end{array}$ & $34 \cdot 22+4 \cdot 13$ & $\begin{array}{l}p<0 \cdot 0005 \\
44 \cdot 25+3 \cdot 6 \\
p<0.0005\end{array}$ & $\begin{array}{l}p<0.0005 \\
43.79 \pm 6.66 \\
p<0.0025\end{array}$ \\
\hline
\end{tabular}

\section{Discussion}

There is ample evidence that in patients with cirrhosis of the liver several components of cell-mediated immunity and humoral immunity are impaired. ${ }^{2}{ }^{2}$ Studies of monocyte function in these patients have been scarce, however, possibly because no routine methods are available for its assessment. Holdstock et al showed in a preliminary publication that monocytes from patients with cirrhosis of the liver have a defect in chemotaxis. ${ }^{8}$ Ganguly et al found increased activity of acid hydrolases in monocytes from patients with cirrhosis of the liver. ${ }^{9}$

Our data show that in patients with cirrhosis of the liver monocyte function as determined by phagocytosis and killing of $C$ albicans and $C$ pseudotropicalis is significantly decreased and that metabolic activity of these cells as measured by chemoluminescence is low. In addition, a dialysable factor with a molecular weight of less than 12000 daltons seems to exist in the patients' serum, which lowers intracellular killing of both Candida species by normal monocytes. We also found that proteolytic treatment of patients' monocytes with trypsin improved their phagocytosis but not their killing ability. The observed differences of action of the serum factor impairing intracellular killing and the fact that trypsinisation of monocytes improves phagocytosis would suggest that more than one factor or mechanism of action plays a part. Various serum proteins impair cellular immunity-for example, ferritin, ${ }^{10} \alpha$-fetoprotein, ${ }^{11}$ and endotoxin. ${ }^{12}$ Of these, only endotoxin has a molecular weight of less than 12000 daltons.

The patients that we studied did not represent a homogeneous group but had liver disease of diverse aetiology. Monocytes have lately been considered to be a component of the monocytemacrophage system, which includes among others Kupffer's cells. There is as yet no evidence that impaired monocyte function in a patient would also point to altered function of Kupffer's cells. While liver macrophages function poorly in liver cirrhosis as indicated by poor clearance of endotoxins from the gastrointestinal tract, ${ }^{13}$ Sherlock $^{3}$ stated that these observations could well be explained by the altered portal circulation causing the liver and its cells to be bypassed. In view of the pivotal role of Kupffer's cells in clearing portal blood a possible decrease in their function like the one we describe in the monocytes could well be extremely important in the development of chronic liver disease. We therefore suggest that future data on the function of Kupffer's cells in patients with cirrhosis of the liver will lead to a better understanding of the pathophysiology of chronic liver disease.

This study was supported in part by grant No 598 from the Chief Scientist's Office of the Israel Ministry of Health.

\section{References}

${ }^{1}$ Berenyi MR, Straus B, Crus D. In vitro and in vivo studies of cellular immunity in alcoholic cirrhosis. American fournal of Digestive Diseases 1974;19:199-205.

2 Thomas HC. The immune response in hepatic cirrhosis: animal and human studies. Proc $R$ Soc Med 1977;70:521-5.

${ }^{3}$ Sherlock S. Immunological changes in liver disease. Proc $R$ Soc Med $1977 ; 70: 851-5$.

4 Van-Furth R, Diesselholf-Den Dulk MCC. The kinetics of promonocytes and monocytes in the bone-marrow. $\mathcal{F}$ Exp Med 1970;132:813-28.

5 Boyum A. Isolation of mononuclear cells and granulocytes from human blood. Scand $\mathcal{F}$ Clin Lab Invest 1968;21, suppl 97:77-89.

6 Territo MC, Cline MJ. Monocyte function in man. $\mathcal{F}$ Immunol 1977 ; 118:187-92.

${ }^{7}$ Allen RC, Yevich SJ, Orth RW, Steele RH. The superoxide anion and singlet molecular oxygen: their role in the microbicidal activity of the polymorphonuclear leukocytes. Biochem Biophys Res Commun 1974;60:909-17.

${ }^{8}$ Holdstock GE, Hill S, Wright R. Peripheral monocytes in chronic liver disease. Gastroenterology 1979;77:A17.

${ }^{9}$ Ganguly NK, Lloyd B, Price CP, et al. Acid hydrolases in monocytes from patients with inflammatory bowel disease, chronic liver disease, and rheumatoid arthritis. Lancet 1978; i:1073-5.

10 Giller S, Moroz H. Ferritin-its structure, chemical and immunological properties and importance in malignant diseases. Harefuah 1978;94: 236-8.

1 Murgita RA, Andersson LC, Sherman MS, Bennich $\mathbf{H}$, Wigzel $\mathbf{H}$. Effects of human alpha-foetoprotein on human $B$ and $T$ lymphocyte proliferation in-vitro. Clin Exp Immunol 1978;33:347-56.

12 Golde LM, Scher I, Osborne B, Rosenstreich L. Cellular mechanism of endotoxin unresponsiveness in $\mathrm{C}_{3} \mathrm{H} / \mathrm{HeJ}$ mice. F Immunol 1976;116: 454-61.

13 Triger DR, Boyer TD, Levin J. Portal and systemic bacteraemia and endotoxaemia in liver disease. Gut 1978;19:935-9.

(Accepted 20 February 1981) 